\title{
The role and the place of the Institute of Culture within a classical university structure
}

\author{
Galina I. Petrova ${ }^{2}$, Irina V. Brylina ${ }^{1}$, Alla A. Kornienko ${ }^{1}$, Natalia V. Bogoryad ${ }^{1, \mathrm{a}}$ \\ ${ }^{1}$ Tomsk Polytechnic University, 634050 Lenin Avenue, 30, Tomsk, Russia \\ ${ }^{2}$ Tomsk State University, 634050 Lenin Avenue, 36, Tomsk, Russia
}

\begin{abstract}
The modern culture, having refused the generality of culture norms and ideals and offering plurality of their samples, confronts social institutes with a problem of choosing the ones, which they are intended to serve. Uppermost, this concerns such a social and educational institute as a university. Where, to what norms and ideals does the modern university lead the student if by opening the world in front of them, it offers a reality of cultural pluralism? How to show the truth if it is seen in its heterogeneous state? What culture and truth does the professor choose to orientate himself/herself in his/her teaching path? May the Institute/ Department of Culture help answer all these questions as being the one that started the history of university? To answer these questions the comparative-historical method of research has been used: the contradiction has been displayed against the background of culture problem solving in the history of the university. The article justifies the need for the development of the philosophical-culturological concept of forming and keeping culture values performed by the institutionalized organizations of the university. The problem of replacing the concept of 'the graduate model' with that of 'the profession model' as a goal of innovative university education has been justified.
\end{abstract}

\section{Introduction}

At present, university education is being faced with a great number of questions. They all in one way or another are connected with serious transformations that are taking place in its criterial bases. This article is devoted to such a criterion of a classical university as its possession of a special spiritual and cultural aura - a criterion, being an invisible and inaudible fluid of the spiritual life [1, p.96], that has always underlined the university specifics. The following may be named as the main factors that influence the content of education today and, in this connection, changes in the university atmosphere. First, the modern university has entered the global educational space with an arising problem of competitive struggle for surviving among other universities of the world level; second, the modern knowledge, by transforming into information, has gained monetary and commercial qualities and, by entering the university, has lead it to the market of educational services; third, commercialization of education, its transformation into an educational service has made adjustments to its classic mission, offering it to become a commercial organization. This is precisely why the topical issue of keeping the specific cultural aura as a criterion of university education arises. Certainly, this criterion and this aura are undergoing relevant temporal changes and acquiring different forms (in comparison with the traditional ones) that must be sought and kept with care. In this connection, extra tasks and a growing amount of responsibility for keeping the culture heritage, which the university has accumulated during the whole history of its existence, are imposed on the university Departments and Institutes of Culture.

\section{Subjects and methods of research}

The problem set in this article is connected with searching for solutions of the following contradiction. On the one hand, the culture values, which the modern university is cherishing, may not be identical to those of the past. Introducing the student to this kind of traditional cultural values would mean to make them maladjusted and prepare for the life that has already gone. It cannot go unnoticed that the information network society has changed the type of a person. Individualism (as a response to the fragmentation of the world) and striving for practical self-fulfilment have become his/her principal characteristics. For such a person, traditional characteristics of self-sufficiency and inner world's integrity are not important. Today, the individual is an "actor", i.e. a person for whom there is no point in the inner spiritual and value content; finding

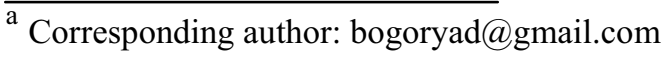


and displaying themselves in some kind of activity seems to be of great importance for them. This person does not think in terms of the eternity and metaphysics of the life values. Their thesaurus simply does not contain them, as they are not connected with pragmatic or practical life programs. On the other hand, refusing the metanarrative values and accepting a hyper individualistic position turns into their individual framing because they still have to live in the society, which has become interdependent under the conditions of globalization. Within a specific life situation, the individual-actors are bound to restrain their absolute individualism in order to identify themselves in the social community.

Within the university, this contradiction is of concern and is solved with the involvement of an Institute/ Department of Culture whose role and responsibility are growing under conditions of the modern world. The purpose of this paper is to show how the institute/ department may cope with this role, what is offered by the scientific literature, and on what theoretical basis may this contradiction be solved.

The method used for the research of the problem set is defined as a comparative historical one: the problem contradiction will be shown against the background of solving culture problems in the university history.

Many authors, including those of our country and the foreign ones, turned to the solution of this problem. Among the authors who were interested in the question on the cultural values of the university, it is necessary to mention I. Kant [2, 257-347]. F. Schleiermacher [3] addressed the spiritual and cultural identity of the university education: the attention to this issue was caused by his deep piousness and devotion to romanticism. The author was attracted by the romanticism of religion as a doctrine of the unity of the person with the whole, i.e. the eternity. As Schleiermacher believes, religion is necessary for the university because the created spiritual atmosphere there is due to the religious feeling, and the personality raised understands and contacts the whole - the global harmony and absolute. Religion exalts people, teaches them to perceive the world. Of course, among the classic scholars of philosophy and theory of university a special place belongs to $\mathrm{W}$. von Humboldt. His teaching was largely influenced by the philosophy of neohumanism. The humanistic pathos of Friedrich Schiller's and Johann Gottlieb Fichte's lectures, where they claimed the formation of philosophic minds to be a university merit and showed philosophy as an all-encompassing discipline, introducing to the knowledge integrity, aimed Humboldt at developing the concept of the university [4]. This university with its special 'idea' directed at forming the people's mind was named classical. Much later Max Scheler presented a new understanding of the university $[5,6]$.

At present, the classical university with its characteristics and criteria developed in the philosophical classics is more often under discussion as an institution with no future. This is justified by the fact that under the circumstances of a rapidly flowing cultural, social and professional reality the constant sum of knowledge, to acquisition of which the university has always called, is becoming non-demanded, and under the conditions of the globalized world it has become impossible to talk about a unified national, people's (according to Humboldt) spirit. Some ideas of B. Readings [7], R. Barnett [8] and J-F. Lyotard [9] concerning this aspect are known. The work by $\mathrm{Z}$. Bauman [10, p.2] seems to be also of interest. Among the Russian authors diagnosing the future of the university, the following names should be mentioned: B. Slavin [11], A. Malinkin [12], K. Mikhailov-Gorynya [13], O. Shamina [14].

\section{Results and discussion}

\section{José Ortega y Gasset's position}

Ortega y Gasset [15] provides the ideas of maximum interest concerning solving the abovementioned problems, specifically about the Institute/ Department of Culture and its place in preserving the cultural heritage of the classical university. It is so despite the fact that this philosopher lived and worked in the first half of the $20^{\text {th }}$ century. At the dawn of the $20^{\text {th }}$ century he predicted that teaching such 'great cultural disciplines' as physics (which forms the world framework), biology (which creates the fundamental framework of organic life), history (whose intended purpose is studying the history of humanity), sociology (that gives an insight into the structure and functioning of social life) and philosophy (that generates the framework of the Universe) must become the primary and dominant function of the university. According to Ortega y Gasset, carrying out the mission of synthesizing the ideas of culture of the time, the Institute/ Department of Culture constitutes the core and a dominant idea of the university education. It is important to restore teaching the culture as the system of vitally important notions. Culture is thought of as a level of intellectual development of the humans that corresponds to their era. It provides humans with an opportunity to orient in the world of social chaos and find their own way.

Designing the Institute/ Department of Culture, Ortega y Gasset in fact resurrects the idea of a liberal university by John Henry Newman [16] and actively sets it against the idea of pragmatism that is now gaining power and threatening to turn into a cultural dominant idea. The social mission of the university involves concentrating efforts on developing the cultural ideal of the age, explaining the liability for the destinies of humanity to the intellectuals and arousing their 'sense of mission'.

Transformations of the modern culture make the university society pay attention to the fact that the university commitment to the scientific knowledge, formed in the 19th century, is making its present importance actual in order to see science against the general cultural background. It is not the pure science, that may be interesting to the modern university, but the science within culture. This is due to the fact that science in the $20^{\text {th }}$ century, as well as knowledge in general, has 
not only the traditional gnoseological function of searching for the truth, but also it has acquired monetary and commercial qualities and is being transformed into a commercial institution. In this form, science is not identical to the culture, as it is not concerned with the character of its mastering and application; therefore, entering the university, it dilutes its spiritual identity. Therefore, the idea of Ortega y Gasset concerning the necessity to place the Institute/ Department of Culture in the centre of the whole university education structure sounds more relevant. Such reorganization could facilitate the solution to complicated pragmatic and technocratic problems that the modern university is facing (in particular, those of commercialization). The point is not in denying the commercial opportunities of the university (education is non-commercial in itself, however, it also has commercial opportunities), but in mastering the culture of translating these possibilities into action. The Institute/ Department of Culture is allotted with a task of organizing the university space in such a way that pragmatism of modern education include a humanistic charge. What prospects in this regard seem to be possible?

\section{The interest of the modern university: 'science in culture'}

In the circumstances of the present-day state of culture, it has become obvious that liberal arts education may not be the prerogative for the departments of humanities and study within the liberal art and social science disciplines. Today humanization of education implies the development of new approaches to understanding of the necessity of studying the human in their all-round interaction with nature. The solution of this question is connected with the removal of the formed alienation of the human from nature through filling the natural science education with the liberal art content. Of course, natural and technical branches of science are characterized by the irrelevance to the inner state of the human, and their logical structure seems to be independent of social conditions. However, humanism of science as its correspondence with the human and society reveals itself in several planes. The main of them is that any knowledge is the knowledge of humanity and bears data on the laws of nature as objective ones. But first, it is put through the filter of human consciousness, which has perceived them, and second, through the language that this knowledge is spoken out with and formulated into laws. Knowledge always bears human subjectivity, therefore, any knowledge is that of liberal art.

The problem of liberal arts and exact sciences ratio in the education system has a long history. At the origins of education - in Ancient Greece - there was not any division into various areas of knowledge. Even in the Middle Ages, the knowledge received in the process of education formed the unified pattern of the world around. However, with the start of the Renaissance, humanism as a cultural movement was of value in the European education, proclaiming the power of the human intellect, freedom of spirit and titanism of human achievements. This constituted science as a social institution. The new age, when science determined its applicable importance and began to embody and materialize itself in technology, when it brought technical and industrial changes, thus developing and deepening its specialization. The industrial revolution put an end to the idea of indivisibility of knowledge in the education system, when a freshman or sophomore student by learning philosophy got acquainted with the general and integral system of knowledge. In the $20^{\text {th }}$ century, in connection with the introduction of complex technologies, automation development and cybernation, there was a growth of illusion regarding the obsolescence and irrelevance of liberal art education in the world of the future. This tendency reached its climax in the middle of the $20^{\text {th }}$ century under the influence of large achievements in science, like acquisition of atomic nuclear energy, discoveries in the area of inorganic chemistry, human exit into space, etc. By the end of the 20th century, the idea of unity between the liberal art and natural science knowledge had started to realize. The process that began in education was reconsideration of the problem concerning the expediency of training students from other majors in liberal art, as well as of the problem of synthesizing the liberal art sciences with those of other science branches. It is possible to exemplify many universities of the world, where this reconsideration took place: Worcester Polytechnic Institute and Technische Universität Darmstadt (Darmstadt Technical University). What tendencies in solving this problem, after examining similar experience and simultaneously considering the Russian context, may be taken into account by our university?

\section{Possible and necessary transformations of education and studying in the modern university}

The foundation for selecting such tendencies must follow the principle of unity between the natural science and liberal art education, as well as training the specialist who understands this unity and possesses 'double literacy'. Implementation of this principle may be different depending on the specific conditions of the specific university. However, what could be offered instead?

First, teaching today must include such educational course curricula in which appropriate attention would be given to the projects under consultation. In its character, the projects must be interdisciplinary. In the course of fulfilling these projects, students must demonstrate their skills of synthesizing knowledge gained in the study room, formulating and independently investigating the subject and prepare regular reports on their activity. In the designing work, students acquire skills of planning, research, analysis, etc. - the skills of liberal art support their research activity. The projects concern both specific professional areas and areas of liberal art and social sciences. Each student must choose the course cycle in liberal art disciplines that will be approved at an individual consultation with the teacher. The result of such work will be a research essay or methodological 
study. Each student will work for a certain amount of time to fulfil a complex qualifying project. The task of the project assumes that in the course of its fulfilment, the student will study a certain example to investigate the impact of science and technology on the social aspects in the life of the society.

Second, the student is bound to defend the main qualification project in their major. It may be carried out by a group of students under supervision of a professor. It is possible (and should be encouraged) that the topic of the project is offered by outside organizations. Both types of projects encourage students to practical activity and development of their research skills using the class work results and life problem solutions.

Third, based on the Institute/ Department of Culture, it is necessary to create an Interdisciplinary Research Centre [17]. Its main purpose is to initiate and support the research activity that is connected with solving problems that concern the development of technology and society. The key function of the Centre is to support the interaction between the natural and social sciences and provide introduction of research results to the interdisciplinary program of education. By supporting the corresponding projects, the Interdisciplinary Research Centre:

1. Assists in the rational understanding of the science discovery context and application of its results in technology.

2. Determines the importance of technology for social development.

3. Carries out the humanitarian inspection of research and technology studies and their consequences.

4. Based on the accepted research projects, it forms the main tendencies of work: science, technology, and safety policy; international information exchange; local regional ecological planning, technology, labour and education. Within the Centre, interdisciplinary research projects reach interaction between technology and culture.

Fourth, the methodological and didactic area of the modern university education is changing towards the necessity of teaching not so much the subject and discipline knowledge of separate sciences. Active attention should be paid to the character of subjective humans activity, the exact means of humans work in science, methods and procedures of their activity in technology. Education has reached the methodology which testifies the world to be not the one objectively alienated from the human and being in the relation of dichotomy with them, but world is embedded into the structure of the human themselves. The world is a part of humanity, its image and state depends on how the human creates it. In this regard, in the university education, it is important to give appropriate attention to the general technology disciplines that are presently acquiring the importance of the liberal and culturological arts, like, for instance, system design. Design inserts the idea of world structuring according to the laws of beauty into the human consciousness, and since any human in any fragment of reality creates their own world, the comprehension of design has a wider scope of importance than only professional one at a specific department. It gives the student knowledge for humanization of an area of technological or natural reality. At present interdisciplinary importance, like in design, is given to such disciplines as basics of nature management, economics and technology, social psychology, professional psychology and basics of management. Today, without possession of knowledge in the area of these disciplines, it is impossible to be a good professional in any area.

The liberal art potential of such work is justified by the fact that this program is considered to be not just the central one; it has a character of a humanitarian principle, when it is the liberal art characteristic of science which binds its special disciplines and returns integrity and unity to science. The modern liberal art education is acquiring an instrumental character. It teaches students to use safe methods to introduce themselves to the world.

\section{Conclusion}

In order to bring leading ideas of innovative university education to life in keeping the traditional characteristic of the classical university - its liberal art content - there is presently a concept of profession model under development. This concept is introduced to replace the model of a graduate concept of the past. The difference between these two concepts is brought to the fact that the profession model does not include the statics. That is, those clearly and accurately described qualifications that the specialist must have and that previously, during the years of non-pragmatic thinking of the Russian education, were written in the model of a graduate. This statics is omitted due to the emergence of understanding that in the professional world, which is characterized by features of uncertainty of movement and kaleidoscopic unpredictability of future states, there is impossibility to have a profession, which is not developing or is not complemented by new features. A profession today is a flexible state of personal special knowledge that is being changed under the influence of specific situations and contexts of their character and scope.

In order to be able to make professional adaptation possible in the practical professional activity, studies in the modern university preserve the traditional characteristics of the Russian university. It consists in the fact that the first stage of education includes mastering the social and general cultural relations of the profession and society that determine the content of the subject 'Profession in the Context of Culture'. The second stage has subjects and disciplines that provide understanding of technologies, means and methods of solving the professional tasks. The third block is a methodological one. The advantages of thus constructed innovative university education and a profession model lie in the fact that the student does not have a canonical and firmly fixed image of the profession which demands constancy of the specific (though high) level of professional knowledge. On the contrary, the model includes striving for dynamics and changes in the quality 
of their professional area, as well as development of innovative thinking.

\section{Acknowledgment}

The study was supported by a grant of the Russian Foundation for Humanities №14-13-70004 “The corporate culture of a classical university: its role in the development of professional and personal identity of the graduate". The authors are grateful to the organizers of grant support, to the whole group conducting research in this area, and to the authors of the scientific materials used while writing this paper.

\section{References}

1. K. Jaspers, Idea of the University (Minsk: BSU, 2006)

2. I. Kant, The conflict of the faculties (M.: Thought, 1966)

3. F. Schleiermacher, From the work 'Reflections on University in the German sense'. University idea in the Russian Empire XVIII-early XX centuries. Anthology (M, 2011)

4. I.G. Fichte, Ueber den Begriff der Wissenschaftslehre oder der sogenannten Philosophie (M.: Sotsekgiz, 1935)

5. M. Scheler, Wesen und Formen der Sympathie (M.: Gnosis, 1994)

6. M. Scheler, Logos, Philosophical and literary magazine, 6 (51), 2005.

7. B. Readings, University in ruins (M.: Publishing House State University, Higher School of Economics, 2010)

8. R. Barnett, Imagining the University. Education in Modern Culture (Minsk: Propylaea, 2001)

9. J-F. Lyotard, The Postmodern condition (M.: Publishing House "Alethea", 1998)

10. Z. Bauman, The Individualized Society (M.: Logos, 2002)

11. B. Slavin, The dying-out profession, or why university education has no prospects in the XXI century.

Access: http://www.executive.ru/education/adviser/181084 8/

12. A. Malinkin, Logos, Philosophical and literary magazine, 6 (51), 2005

13. K. Mikhailov-Gorynya, Gumboldt model of university education as the ideological foundation of German fascism: parallels with Russia (2010)

14. O.B. Shamina, Bulletin of the Buryat State University, 6, (2009)

15. Ortega y Gasset, Alma mater, Journal of higher education, 7, (2003)

16. J.H. Newman, Idea of University (Minsk, BSU, 2006)

17. G.I. Petrova, I.V. Brylina, E.G. Kulizhskaya, N.V. Bogoryad, Procedia Social and Behavioral Sciences, 166, 505-510 (2015) 